\title{
Creating a Short Life Site for Prunus Rootstock Evaluation on Land with No Innate Mesocriconema xenoplax Population
}

\author{
A.P. Nyczepir ${ }^{1}$, W.R. Okie ${ }^{2}$, and T.G. Beckman ${ }^{2}$ \\ USDA-ARS, Southeastern Fruit and Tree Nut Research Laboratory, 21 Dunbar \\ Road, Byron, GA 31008
}

Additional index words. Mesocriconema xenoplax, peach tree short life, Prunus persica

\begin{abstract}
Peach tree short life (PTSL) is associated with the presence of ring nematode, Mesocriconema xenoplax, and poor orchard management practices. Finding a noncommercial field site to evaluate rootstocks for PTSL resistance is increasingly difficult. The time needed to create a PTSL test site was investigated. In 1994, a site not planted in peaches for $>\mathbf{8 0}$ years was identified in Byron, Ga. Analysis of preplant soil samples revealed that there were no $M$. xenoplax on the site. One-third of the land was planted to peach and infested with 1600 ring nematodes per tree in Spring 1994 (P2) and another one-third in Spring 1995 (P1). The remaining one-third of the land received no trees or ring nematode and served as the control (F2). In Fall 1995, trees were removed from P1 and P2 plots and all treatments were replanted to peach in 1996. In 1997, tree death resulting from PTSL occurred only in P2 (7\%). By 2000, PTSL tree death reached $41 \%$ in P2, $16 \%$ in P1, and $4 \%$ in $\mathrm{F} 2$ plots. Nematode populations were higher $(P<0.05)$ in P1 (649 ring nematode/ $100 \mathrm{~cm}^{3}$ soil) than in $\mathrm{F} 2$ (221 ring nematode $/ 100 \mathrm{~cm}^{3}$ soil) plots, whereas populations in $P 2$ (300 ring nematode/100 $\mathrm{cm}^{3}$ soil) plots did not differ from those in P1 or F2 plots. Establishing a PTSL screening site was possible 3 years after $M$. xenoplax introduction; PTSL development among treatments in the subsequent planting was dependent upon cumulative population exposure of trees to M. xenoplax.
\end{abstract}

In the southeastern United States, the productive life span of peach trees does not exceed 6 to 10 years on some sites (Brittain and Miller, 1978). Tree death has been attributed to a disease complex termed peach tree short life (PTSL) as reported by Savage and Cowart (1942). The external symptoms of PTSL are similar to those of any plant deprived of an adequate root system (Taylor et al., 1970). Bacterial canker (Pseudomonas syringae pv. syringae van Hall) (Weaver et al., 1974), cold injury (Prince, 1966), or a combination of both are thought to be the final agents of tree death in the PTSL complex (Brittain and Miller, 1978). However, the ring nematode [Mesocriconema xenoplax (Raski) Loof \& de Grisse] (Nyczepir et al., 1983), rootstock(Yadava and Doud, 1989; Zehretal., 1976), scion cultivar(Beckman etal., 1994), cultural practices (Weaver et al., 1974), planting site (Weaver et al., 1974; Yadava and Doud, 1996), and weather (Prince, 1966) are

Received for publication 1 Apr. 2003. Accepted for publication 23 Sept 2003. We thank Ray Adams, Wanda Evans, Hal Lowman, Elaine Heavner, and Roger Laster for technical assistance. Mention of a trademark, proprietary product, or vendor does not constitute a guarantee or warranty of the product by the U.S. Dept. of Agriculture and does not imply its approval to the exclusion of other products or vendors that also may be suitable.

${ }^{1}$ Research Nematologist; to whom reprint requests should be addressed. E-mail address: anyczepir@ saa.ars.usda.gov

${ }^{2}$ Research Horticulturist. factors that weaken trees and/or predispose them to PTSL.

In closed-end field microplots, peach trees died of cold injury after 4 years of parasitism by $M$. xenoplax, while trees in uninfested soil survived (Nyczepiretal., 1983). Subsequently, in the absence of $M$. xenoplax, pruning time alone was not related to PTSL development (Nyczepir, 1990). Such evidence indicates that PTSL is truly a nematode-associated problem and the presence of $M$. xenoplax is required for PTSL to occur. Under South Carolina field conditions, a nematicide treatment threshold of $>50 \mathrm{M}$. xenoplax per 100 $\mathrm{cm}^{3}$ soil is recommended in peach orchards for prolonging tree life on PTSL sites, whereas in Georgia the nematicide treatment threshold is $\geq 1$ M. xenoplax per $100 \mathrm{~cm}^{3}$ soil (Davis et al., 1996; Nyczepir and Halbrendt, 1993). In North Carolina, it was estimated that PTSL tree death was likely at average cumulative population densities of 38-83 M. xenoplax per $100 \mathrm{~cm}^{3}$ soil, with greatest percentage of tree death occurring with an increasing ring nematode population (Ritchie, 1988).

The association of PTSL with "old" peach sites has led to the hypothesis that some predisposing factors persist in old peach orchard sites that make new trees more susceptible to this disease complex (Weaver et al., 1974). However, it has been demonstrated that old peach sites are not a prerequisite and that the presence of M. xenoplax is the most critical biotic component for PTSL development (Nyczepir, 1990). Furthermore, Nyczepir and Okie (1996) substantiated a common pattern in that severity of PTSL on a given site increased after each successive peach planting following a build-up of the M. xenoplax population.

The objective of this research was to determine the time needed to create a PTSL test site for Prunus rootstock evaluation on land with no innate population of M. xenoplax.

\section{Materials and Methods}

Site. The experiment was initiated at the USDA, ARS Southeastern Fruit and Tree Nut Research Laboratory, Byron, Ga. The study was conducted on a Norfolk loamy sand, fine loamy, siliceous, thermic, typic Paleudults soil (86\% sand, $8 \%$ silt, $6 \%$ clay; $1.3 \%$ organic matter) that had been cleared of 80 -year-old pecan trees in 1985, and had no known history of peach production. Since soil pH was 6.1, no preplant liming was required. This site laid fallow for 9 years until establishment of this experiment in 1994 . The test site ( 0.25 ha) was subsoiled down the tree row to a depth of $38 \mathrm{~cm}$, disked, and rotovated in Oct. 1993. Glyphosate (4.5 $\mathrm{kg} \cdot \mathrm{ha}^{-1}$ a.i.) was used for weed control prior to peach planting in Feb. 1994.

The initial soil population density (Pi) of $M$. xenoplax was determined in Feb. 1994, from nine soil cores $(2.5-\mathrm{cm}$-inch diameter $\times 30-\mathrm{cm}$ depth) collected from each of the 12 replicates throughout the test site. The soil cores were composited and nematodes were extracted from a $100-\mathrm{cm}^{3}$ soil subsample with a semiautomatic elutriator (Byrd et al., 1976) and centrifugalflotation (Jenkins, 1964). The soil remaining after the initial extraction was then placed into $10-\mathrm{cm}$-diameter plastic pots and Nemaguard peach (good host for M.xenoplax) was planted to bioassay $M$. xenoplax not detected by elutriation and centrifugation. Four and one-half months later, nematodes were extracted from this soil as described above and counted.

Preliminary planting. Experimental plots consisted of three treatments as follows: peach continuously for 2 years $(\mathrm{P} 2)$; peach for 1 year (P1); and fallow continuously for 2 years (F2), which served as the control. Plot size was $10.9 \times 6.1 \mathrm{~m}$. The treatment plots were arranged in randomized complete blocks with 12 replications per treatment. In Feb. 1994, P2 plots were planted with 'Sunsplash' scion on Nemaguard rootstock at a tree spacing of 6.1 $\times 1.2 \mathrm{~m}$ between rows and trees, respectively. Each plot had 10 trees, with one on each side for uninoculated borders and eight in the center for inoculation with M.xenoplax. In Mar. 1994, ring nematode inocula consisting of $800 \mathrm{M}$. xenoplax adults and juveniles in $100 \mathrm{~mL}$ tap water were added to two furrows $(11 \mathrm{~cm}$ long $\times 7 \mathrm{~cm}$ wide $\times 8 \mathrm{~cm}$ deep), one on either side of each of the center trees (i.e., 1600 nematodes per tree). Furrows were covered with soil following nematode inoculation. Treatment plots $\mathrm{P} 1$ and F2 were left unplanted and uninoculated in 1994, and were treated with glyphosate to control weeds. In Jan. 1995, P1 plots were planted with 'Sunsplash' scion on Nemaguard rootstock and inoculated as described above with M. xenoplax in Mar. 1995. However, F2 plots remained unplanted, uninoculated, and 
Table 1. Populations of Mesocriconema xenoplax (1996 to 2000) on Nemaguard peach as influenced by three preliminary planting regimes (P2, P1, and F2) on a Byron, Ga., site not in peaches for $>80$ years $(\mathrm{n}=12)$.

\begin{tabular}{|c|c|c|c|c|c|c|c|c|c|}
\hline \multirow[b]{2}{*}{ Treatment $^{2}$} & \multicolumn{9}{|c|}{ No. of nematodes $/ 100 \mathrm{~cm}^{3}$ soil } \\
\hline & Jan. $1996^{y}$ & Dec. 1996 & Apr. 1997 & Dec. 1997 & Mar. 1998 & Dec. 1998 & Mar. 1999 & Dec. 1999 & Apr. 2000 \\
\hline$\overline{\mathrm{P} 2^{\mathrm{x}}}$ & $129 \mathrm{a}^{\mathrm{w}}$ & $701 \mathrm{a}$ & $610 \mathrm{a}$ & $636 \mathrm{a}$ & $659 \mathrm{~b}$ & $461 \mathrm{a}$ & $313 \mathrm{a}$ & $1054 \mathrm{a}$ & $300 a b$ \\
\hline $\mathrm{P} 1^{\mathrm{v}}$ & $3 \mathrm{~b}$ & $200 \mathrm{~b}$ & $234 \mathrm{~b}$ & $1181 \mathrm{a}$ & $1575 \mathrm{a}$ & $1082 \mathrm{a}$ & 899 a & 706 a & 649 a \\
\hline $\mathrm{F} 2$ & $0 \mathrm{~b}$ & $0 \mathrm{c}$ & $0 \mathrm{c}$ & $13 \mathrm{~b}$ & $12 \mathrm{c}$ & $60 \mathrm{~b}$ & $78 \mathrm{~b}$ & $184 \mathrm{~b}$ & $221 \mathrm{~b}$ \\
\hline
\end{tabular}

${ }^{\mathrm{z}} \mathrm{P} 2=2$ years of continuous peach (1994-96) prior to replanting site with peach; $\mathrm{P} 1=1$ year of peach (1995-96) prior to replanting site with peach; and F2 = 2 years continuous fallow (1994-96) prior to replanting site with peach in Jan. 1996.

yPreplant M. xenoplax population density prior to replanting entire site with peach in Jan. 1996.

${ }^{x}$ Each P2 tree initially inoculated with 1600 juvenile and adult M. xenoplax in Mar. 1994 following planting in Feb. 1994.

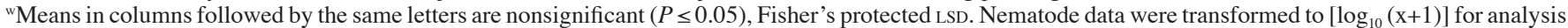
and were back-transformed for presentation in this table.

${ }^{v}$ Each P1 tree initially inoculated with 1600 juvenile and adult M. xenoplax in Mar. 1995 following planting in Jan. 1995

only managed for weeds. Trees were not irrigated, and were grown as recommended by the Georgia Cooperative Extension Service.

Final planting. In Nov. 1995, all trees were removed from both $\mathrm{P} 2$ and $\mathrm{P} 1$ plots. Care was taken not to transport soil among the plots during tree removal and throughout the remainder of the study. The population density of M.xenoplax, prior to replanting $\mathrm{P} 1, \mathrm{P} 2$, and $\mathrm{F} 2$ plots back with 'Redhaven' scion on Nemaguard rootstock, was determined in Jan. 1996 from eight soil cores collected from within each replicate. The eight soil cores were composited and nematodes extracted from a $100-\mathrm{cm}^{3}$ soil subsample as described above. In Jan. 1996, all plots were planted with 'Redhaven' trees on Nemaguard rootstock at a tree spacing of $6.1 \times$ $1.2 \mathrm{~m}$. Each plot had 10 trees, two for outside borders of nematode-free trees and eight in the center as experimental trees. Nonbearing and bearing trees were not irrigated, and were culturally maintained as recommended by the Georgia Cooperative Extension Service. Trees were pruned in Jan. 1997 and then in Dec. 1998 and 1999 to encourage PTSL-induced tree death (Okie et al., 1994).

Mesocriconema xenoplax population density was monitored beneath the canopy of each tree in Dec. 1996, Apr. and Dec. 1997, Mar. and Dec. 1998, Mar. and Dec. 1999, and Apr. 2000 , from one soil core collected from inside the drip line of each of the eight test trees of every treatment replicate. The eight soil cores were composited and nematodes extracted as described above.

Trunk diameter was measured at $20 \mathrm{~cm}$ above the soil line in Jan. 1997, 1998, 1999; and Feb. 2000. Tree mortality from PTSL was recorded in Apr. 1997 and 1998, and May 1999 and 2000

Nematode data were transformed to $\log _{10}$ $(\mathrm{x}+1)$ values and subjected to analysis of variance (ANOVA) using the general linear model(GLM) procedure of SAS (SAS Institute, 1988). Actual numerical nematode data were used for presentation in tables. ANOVA was also performed to determine treatment effect on trunk diameter. For evaluating final planting, nematode population and trunk diameter means were compared using Fisher's protected least significant difference (LSD) test following a significant $F$ test. Peach tree survival data for each experimental unit were analyzed for each sampling date using ANOVA. Only significant differences $(P \leq 0.05)$ were discussed unless stated otherwise.

HortScience, Vol. 39(1), February 2004

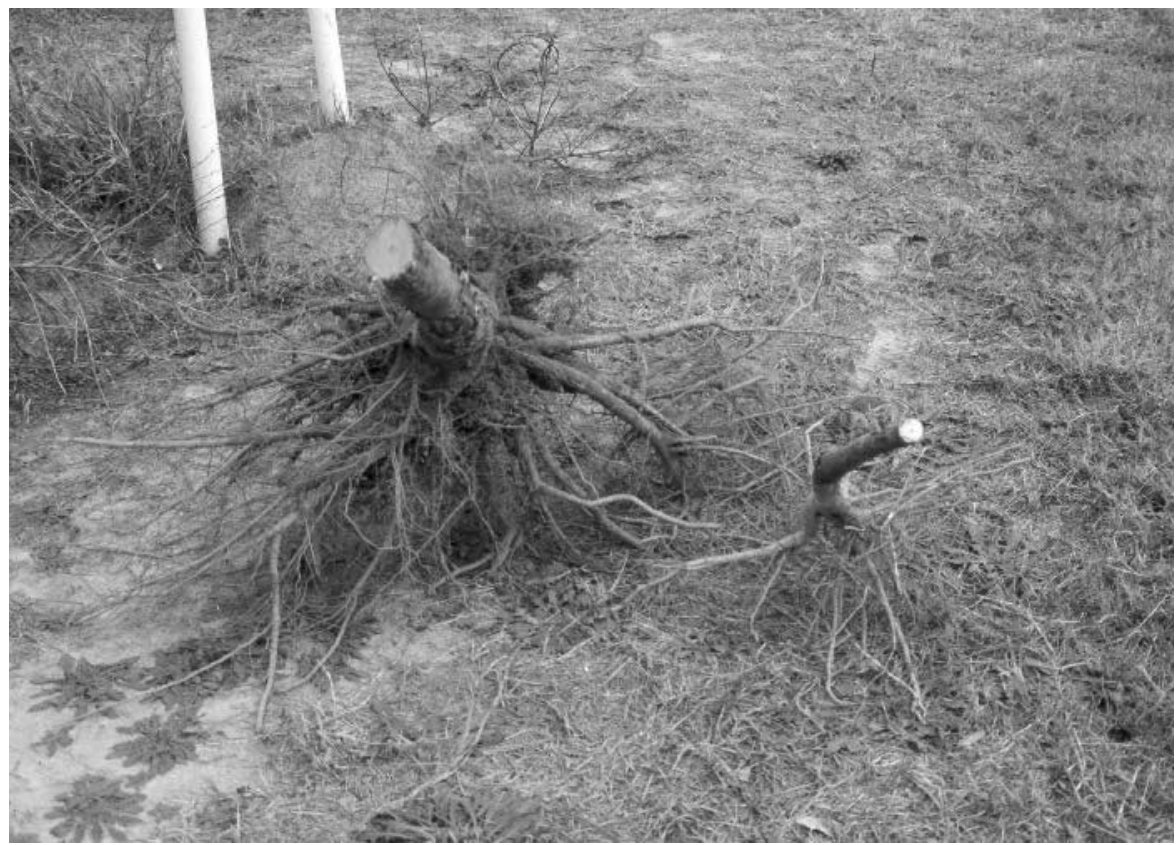

Fig. 1. Typical root system of 'Sunsplash' peach trees on Nemaguard rootstock obtained from P2 (left) and P1 (right) plots in Nov. 1995, prior to replanting with trees of 'Redhaven' peach on Nemaguard rootstock in Jan. 1996.

\section{Results and Discussion}

Preliminary planting. No M.xenoplax was detected in any preplant samples from the 12 plots or in the soil bioassayed with Nemaguard peach in the greenhouse, indicating the absence of M. xenoplax in this test site. The nematode population density in Jan. 1996, following establishment of P2, P1, and F2 plots, but just prior to replanting peach trees, was higher $(P$ $\leq 0.05)$ in $\mathrm{P} 2$ plots than in either $\mathrm{P} 1$ or $\mathrm{F} 2$ (Table 1). This is not surprising since trees in $\mathrm{P} 2$ plots had larger root system than trees in the P1 plots as a result of a longer growing period before their removal in Nov. 1995 (21 months vs. 10 months, respectively) (Fig. 1). Larger root system would mean availability of greater food source for nematode feeding and reproduction to occur. Additionally, the nematodes under $\mathrm{P} 2$ trees had a longer period of time to become established than under P1 trees (20 vs. 8 months, respectively).

Final planting. Nematode populations were the highest $(P \leq 0.05)$ in $\mathrm{P} 2$ plots, intermediate in $\mathrm{P} 1$, and undetectable in F2 plots after 11 and 15 months (Dec. 1996 and Apr. 1997), respectively, of establishing peach trees in all plots (Table 1). In Dec. 1997 (23 months after orchard establishment), the M.xenoplax population density in F2 plots was lower than in P2 and P1 plots, which showed no differences between them. This indicated a transition in the M.xenoplax population density among the three preliminary planting regimes since it is the first time that: 1) no differences were found between the number of ring nematodes detected in P2 and P1 plots; and 2) M. xenoplax was detected in F2 plots. Extreme care was taken during sampling and orchard management operations to prevent cross-contamination of $M$. xenoplax among the treatment plots during this experiment. One explanation as to why ring nematodes became established in F2 plots may be the result of subsoiling that occurred during site preparation of the planting rows. Subsequently, over time the roots among adjacent treatment plots eventually grew down the subsoil furrow, which facilitated nematode movement and establishment of $M$. xenoplax in the F2 plots from adjacent P2 and/or P1 plots.

Twenty-six months after orchard establish- 
Table 2. Effect of three preliminary planting regimes (P2, P1, and F2) on trunk diameter of 'Redhaven' trees on Nemaguard on a Byron, Ga., site not in peaches for $>80$ years $(n=12)$.

\begin{tabular}{lcccc}
\hline & \multicolumn{4}{c}{ Trunk diam (mm) } \\
\cline { 2 - 5 } Treatment $^{\mathrm{z}}$ & Jan. 1997 & Jan. 1998 & Jan. 1999 & Feb. 2000 \\
\hline F2 & $26.3 \mathrm{a}^{\mathrm{y}}$ & $51.2 \mathrm{a}$ & $61.7 \mathrm{a}$ & $66.3 \mathrm{ab}$ \\
$\mathrm{P}^{\mathrm{x}}$ & $27.0 \mathrm{a}$ & $52.3 \mathrm{a}$ & $64.4 \mathrm{a}$ & $70.1 \mathrm{a}$ \\
$\mathrm{P}^{\mathrm{w}}$ & $24.0 \mathrm{a}$ & $45.4 \mathrm{~b}$ & $56.1 \mathrm{~b}$ & $61.8 \mathrm{~b}$ \\
\hline
\end{tabular}

${ }^{2} \mathrm{P} 2=2$ years of continuous peach (1994-96) prior to replanting site with peach; P1 = 1 year of peach (1995-96) prior to replanting site with peach; and F2 = 2 years continuous fallow (1994-96) prior to replanting site with peach in Jan. 1996

${ }^{y}$ Means in columns followed by the same letters are nonsignificant $(P \leq 0.05)$, Fisher's protected LSD.

${ }^{x}$ Each P1 tree initially inoculated with 1600 juvenile and adult $M$. xenoplax in Mar. 1995 following planting in Jan. 1995.

${ }^{\text {wEach P} 2 ~ t r e e ~ i n i t i a l l y ~ i n o c u l a t e d ~ w i t h ~} 1600$ juvenile and adult M. xenoplax in Mar. 1994 following planting in Feb. 1994.
Table 3. Effect of three preliminary planting regimes (P2, P1, and F2) on development of peach tree short life (PTSL) of 'Redhaven' trees on Nemaguard on a Byron, Ga., site not in peaches for $>80$ years $(n=12)$.

\begin{tabular}{lcccc}
\hline & \multicolumn{4}{c}{ Cumulative PTSL mortality (\%) } \\
\cline { 2 - 5 } Treatment $^{\mathrm{z}}$ & Apr. 1997 & Apr. 1998 & May 1999 & May 2000 \\
\hline F2 & $0 \mathrm{a}^{\mathrm{y}}$ & $0 \mathrm{a}$ & $0 \mathrm{a}$ & $4 \mathrm{a}$ \\
$\mathrm{P}^{\mathrm{x}}$ & $0 \mathrm{a}$ & $0 \mathrm{a}$ & $0 \mathrm{a}$ & $16 \mathrm{a}$ \\
P2 $^{\mathrm{w}}$ & $7 \mathrm{~b}$ & $7 \mathrm{~b}$ & $22 \mathrm{~b}$ & $41 \mathrm{~b}$ \\
\hline
\end{tabular}

${ }^{2} \mathrm{P} 2=2$ years of continuous peach (1994-96) prior to replanting site with peach; P1 = 1 year of peach (1995-96) prior to replanting site with peach; and F2 = 2 years continuous fallow (1994-96) prior to replanting site with peach in Jan. 1996.

${ }^{\mathrm{y}}$ Means in columns followed by the same letters are nonsignificant $(P \leq 0.05)$, Fisher's protected LSD.

${ }^{x}$ Each P1 tree initially inoculated with 1600 juvenile and adult M. xenoplax in Mar. 1995 following planting in Jan. 1995.

${ }^{w}$ Each P2 tree initially inoculated with 1600 juvenile and adult M. xenoplax in Mar. 1994 following planting in Feb. 1994. ment (Mar. 1998), nematode populations were the highest $(P \leq 0.05)$ in $\mathrm{P} 1$ plots, intermediate in P2, and the lowest in F2 plots. As in Dec. 1997, M. xenoplax population density was greater in P2 and P1 plots than in F2 plots during Dec. 1998 and Mar. and Dec. 1999. Again no differences were detected between the number of M. xenoplax in $\mathrm{P} 2$ and $\mathrm{P} 1$ plots on these sampling dates. In Apr. 2000 (51 months after orchard establishment), the population density of M. xenoplax in $\mathrm{P} 1$ plots was higher than in F2 plots. The nematode populations in $\mathrm{P} 2$ plots did not significantly differ from those detected in P1 or F2 plots.

Differences in trunk diameter were detected among the preliminary planting regime treatments on three of the four sampling dates (Table 2 ). No differences in tree growth expressed as an increase in trunk diameter were detected 12 months (Jan. 1997) after orchard establishment; however, in Jan. 1998 and 1999 (after 24 and 36 months, respectively), tree growth was the lowest $(P \leq 0.05)$ for trees in $\mathrm{P} 2$ plots than for trees in $\mathrm{P} 1$ and $\mathrm{F} 2$ plots. In Feb. 2000 (49 months after orchard establishment), tree growth was the highest $(P \leq 0.05)$ for trees in $P 1$ plots and the lowest in $\mathrm{P} 2$ plots. No differences in tree growth were detected between $\mathrm{F} 2$ and $\mathrm{P} 2$ or $\mathrm{P} 1$ plots. On most sampling dates, tree growth was generally less in $\mathrm{P} 2$ plots than in $\mathrm{P} 1$ plots. One explanation might be initial nematode population density pressure (Pi). Planting a young tree in soil infested with a greater number of well established M. xenoplax (i.e., P2 soil in Jan. 1996) than in soil with fewer nematodes present (i.e., P1 soil in Jan. 1996) would result in greater nematode feeding damage; thus inhibiting root and shoot growth of trees. The current results from the field trial appear similar to those from earlier studies in the greenhouse and field in that growth of Nemaguard peach in presence of $M$. xenoplax was dependent on $\mathrm{Pi}$, duration of the experiment, and the rate of nematode reproduction (Nyczepir and Okie, 1996; Nyczepir et al., 1987).

Peach trees developed typical PTSL symptoms and died during the experiment. The first incidence of PTSL tree death occurred in Apr. 1997. In Apr. 1997, May 1999, and May 2000 $(15,40$, and 52 months after trees were planted, respectively), more $(P \leq 0.05)$ trees in $\mathrm{P} 2$ plots developed PTSL and died than in P1 or F2 plots (Table 3). No PTSL tree death occurred in 1998. Possibly, climatic conditions were unsuitable for PTSL development (Prince, 1966). Additionally, PTSL tree death did not occur in P1 or F2 plots during 1997-99. The first detection of PTSL tree death in P1 and F2 plots occurred 52 months after orchard establishment (May 2000). The early occurrence of PTSL tree death in P2 plots could be attributed to a higher $M$. xenoplax soil population (129 M. xenoplax per $100 \mathrm{~cm}^{3}$ soil) than in $\mathrm{P} 1(3 \mathrm{M}$. xenoplax per $100 \mathrm{~cm}^{3}$ soil) or F2 (no detectable M.xenoplax) plots at the time of orchard establishment in Jan. 1996. Although M. xenoplax populations in $\mathrm{P} 2$ and $\mathrm{P} 1$ plots were similar at 23 months after orchard establishment (Dec. 1997), trees in $P 2$ plots were exposed to much higher populations than those trees in $\mathrm{P} 1$ plots during the first 2 years.

In our previous study (Nyczepir and Okie, 1996), we were unable to observe PTSL tree death on a virgin site in 6 years despite infesting the soil with $M$. xenoplax at planting. However, $37 \%$ of replanted trees in the subsequent planting died from PTSL within 3 years. In the present study, a 1-year preliminary peach planting (P1) with M. xenoplax resulted in minimal PTSL tree death (16\%) within 4 years in the subsequent planting, whereas a 2 -year preliminary planting of peach (P2) was sufficient to produce $>40 \%$ PTSL tree death during the same period of time. It appears that development of PTSL varies with exposure of trees to the cumulative population of $M$. xenoplax.

\section{Literature Cited}

Beckman, T.G., W.R. Okie, and A.P. Nyczepir. 1994. Influence of scion cultivar on incidence of peach tree short life, p. 45-48. Proc. 6th Stone Fruit Decline Wkshp., 26-28 Oct. 1992, Fort Valley State College, Ft. Valley, Ga.

Brittain,J.A. and R.W. Miller. 1978. Managing peach tree short life in the Southeast. Clemson Univ. Coop. Agr. Ext. Serv., Circ. 585.

Byrd,D.W., Jr., K.R. Barker, H. Ferris, C.J. Nusbaum, W.E. Griffin, R.H. Small, and C.A. Stone. 1976. Two semi-automatic elutriators for extracting nematodes and certain fungi from soil. J. Nematol. 8:206-212.

Davis, R.F., P. Bertrand, J.D. Gay, R.E. Baird, G.B. Padgett, E.A. Brown, F.F. Hendrix, and J.A. Balsdon. 1996. Guide for interpreting nematode assay results. Univ. Ga. Coop. Ext. Serv. Bul. 834.

Jenkins, W.R. 1964. A rapid centrifugal-flotation technique for separating nematodes from soil.
Plant Dis. Rptr. 48:692.

Nyczepir, A.P. 1990. Influence of Criconemella xenoplax and pruning time on short life of peach trees. J. Nematol. 22:97-100.

Nyczepir, A.P. and J.M. Halbrendt. 1993. Nematode pests of deciduous fruit and nut trees, p. 381-425. In: K. Evans, D.L. Trudgill, and J. M. Webster (eds.). Plant parasitic nematodes in temperate agriculture. CAB Intl., Wallingford, Oxon, U.K.

Nyczepir, A.P. and W.R. Okie. 1996. Occurrence of peach tree short life on a field site with no history of peach production. HortScience 31:163.

Nyczepir, A.P., C.C. Reilly, and W.R. Okie. 1987. Effect of initial population density ofCriconemella xenoplax on reducing sugars, free amino acids, and survival of peach seedlings over time. J. Nematol. 19:296-303.

Nyczepir,A.P., E.I.Zehr, S.A. Lewis, and D.C. Harshman. 1983. Short life of peach trees induced by Criconemella xenoplax. Plant Dis. 67:507-508.

Okie, W.R., G.L. Reighard, T.G. Beckman, A.P. Nyczepir, C.C. Reilly, E.I. Zehr, W.C. Newall, Jr., and D.W. Cain. 1994. Field screening Prunus for longevity in the southeastern United States. HortScience 29:673-677.

Prince, V.E. 1966. Winter injury to peach trees in central Georgia. Proc. Amer. Soc. Hort. Sci. 88:190-196.

Ritchie, D.F. 1988. Population dynamics of ring nematodes and peach tree short life in North Carolina, p. 34-37. Proc. 3rd Stone Fruit Decline Wkshp., 28-29 Oct. 1986, Clemson Univ., Clemson, S.C.

SAS Institute, Inc. 1988. SAS/STAT guide forpersonal computers. Vers. 6.03 ed. SAS Inst., Cary, N.C.

Savage, E.F. and F.F. Cowart. 1942. Factors affecting peach tree longevity in Georgia. Georgia Agr. Expt. Sta. Res. Bul. 219.

Taylor, J., J.A. Briesbrock, F.F. Hendrix, Jr., W.M. Powell, J.W. Daniel, and F.L. Crosby. 1970. Peach tree decline in Georgia. Georgia Agr. Expt. Sta. Res. Bul. 77.

Weaver, D.J., E.J. Wehunt, and W.M. Dowler. 1974. Association of tree site, Pseudomonas syringae, Criconemoides xenoplax and pruning date with short life of peach trees in Georgia. Plant Dis. Rptr. 58:76-79.

Yadava, U.L. and S.L. Doud. 1989. Rootstocks and scion influence growth, productivity, survival, and short life-related performance of peach trees. J. Amer. Soc. Hort. Sci. 114:875-880.

Yadava, U.L. and S.L. Doud. 1996. Influence of planting site and rootstock on peach tree short life performance of 'Redhaven' trees. J. Tree Fruit Production 1:55-65.

Zehr, E.I., R.W. Miller, and F.H. Smith. 1976. Soil fumigation and peach rootstocks for protection against peach tree short-life. Phytopathology 66:689-694 